\title{
A New Strategy for the Preparation of N-Aminopiperidine Using Hydroxylamine-O-Sulfonic Acid: Synthesis, Kinetic Modelling, Phase Equilibria, Extraction and Processes
}

\author{
E. Labarthe, A. J. Bougrine, Véronique Pasquet, H. Delalu \\ Laboratoire Hydrazines et Composés Energétiques Polyazotés, UMR CNRS-CNES-SME-Groupe Safran, \\ Université Claude Bernard Lyon 1, Villeurbanne, France \\ Email: veronique.pasquet@univ-lyon1.fr
}

Received February 12, 2013; revised March 12, 2013; accepted April 2, 2013

Copyright (C) 2013 E. Labarthe et al. This is an open access article distributed under the Creative Commons Attribution License, which permits unrestricted use, distribution, and reproduction in any medium, provided the original work is properly cited.

\begin{abstract}
A new strategy for the synthesis of N-aminopiperidine (NAPP) was developed using hydroxylamine-O-sulfonic acid (HOSA). A systematic study of NAPP formation and degradation reactions was carried out in diluted medium, in order to identify products and to establish a kinetic modelling. Principal parameters have been defined, in particular, that obtaining high yields $(>90 \%)$ requires non stoichiometric conditions. The extraction and purification processes were also studied. NAPP isolation and piperidine recycling were optimized after the establishment of the various solid-liquidliquid and liquid-vapour implied phase diagrams. At least, a calorimetric study of solvatation and reaction enthalpies was undertaken in order to estimate reactor heating temperature in the case of anhydrous synthesis. The combination of our kinetic, thermodynamic and calorimetric data allows the establishment of two process schemes: one using pure piperidine, the other, a $66 \mathrm{w} \%$ titrating azeotropic solution in piperidine.
\end{abstract}

Keywords: Natural Asset; Financial Value; Neural Network

\section{Introduction}

$\mathrm{N}$-aminopiperidine (NAPP) is an exocyclic hydrazine often used in pharmaceutical industries. We find it in several medication or molecules in progress.

First, NAPP is encountered in molecules which are ligands of cannabinoid receptors. These latters present an interest in the obesity treatment and in the psychiatric and neurological disorders treatments. These molecules are actually studied by many chemical groups such as Sanofi-Aventis [1], Solvay [2-4], Merck [5,6], Bayer [7, 8], Pfizer [9], Astrazeneca [10,11], Bristol-Myers Squibb [12].

Second, we meet this hydrazine in $\alpha$-substituted benzylnaphtyl and benzylthiophene derivates, used for the treatment of diseases such as osteoporosis, breast cancer, and uterine and endometrial fibrosis. For instance, NAPP is employed as potential intermediate in a Raloxifene ${ }^{\circledR}$ analogue [13].

NAPP also appears in the synthesis of pyridine-2-carboxamide derivatives which are applied in cancer treatment [14].

In view of the great potential of this hydrazine, we have decided to propose a new synthesis strategy by employing the hydroxylamine-O-sulfonic acid (HOSA) reagent. We also defined the extraction steps in order to propose a relevant purification process. In conformity with the particularly restricting pharmaceutical applications, this latter requires then the study of the solid-liquid-liquid and liquid-vapour binary and ternary phase diagrams, in order to optimize the successive unitary extraction operations.

\section{Results and Discussion}

NAPP $\left(\mathrm{C}_{5} \mathrm{H}_{10} \mathrm{NNH}_{2}\right)$ is obtained by reaction between piperidine $\left(\mathrm{C}_{5} \mathrm{H}_{10} \mathrm{NH}\right.$ or $\left.\mathrm{PP}\right)$ and $\mathrm{HOSA}\left(\mathrm{NH}_{2} \mathrm{OSO}_{3} \mathrm{H}\right)$ :

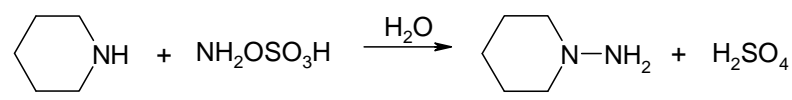

Kinetic studies of formation and degradation were carried out in basic medium in order to neutralize the released sulphuric acid [15].

The constant of formation $k_{1}$ and oxidation $k_{2}$ of NAPP in basic medium at $293 \mathrm{~K}$ are as follows: 
$k_{1}=3.39 \pm 0.10 \mathrm{M}^{-1} \cdot \min ^{-1}$

$k_{2}=1.17 \pm 0.04 \mathrm{M}^{-1} \cdot \mathrm{min}^{-1}$

Formation and oxidation reactions were found to be of first order.

The influence of the temperature was studied from 283 to $303 \mathrm{~K}$, showing that the variation of $k_{1}$ versus temperature obeys to the Arrhénius law.

We have also proposed a kinetic model, taking into account all the reactions of formation and degradation of the mixture:

$$
\begin{gathered}
\mathrm{NH}_{2} \mathrm{OSO}_{3} \mathrm{H}+\mathrm{OH}^{-} \rightarrow \mathrm{NH}_{2} \mathrm{OSO}_{3}^{-}+\mathrm{H}_{2} \mathrm{O} \\
\mathrm{NH}_{2} \mathrm{OSO}_{3}^{-}+\mathrm{C}_{5} \mathrm{H}_{10} \mathrm{NH} \stackrel{k_{1}}{\longrightarrow} \mathrm{C}_{5} \mathrm{H}_{10} \mathrm{NNH}_{2}+\mathrm{HSO}_{4}^{-} \\
\mathrm{OH}^{-}+\mathrm{HSO}_{4}^{-} \rightarrow \mathrm{SO}_{4}^{2-}+\mathrm{H}_{2} \mathrm{O} \\
\mathrm{C}_{5} \mathrm{H}_{10} \mathrm{NNH}_{2}+\mathrm{NH}_{2} \mathrm{OSO}_{3}^{-} \stackrel{k_{2}}{\longrightarrow} \\
\mathrm{C}_{5} \mathrm{H}_{10} \mathrm{~N}^{+}=\mathrm{N}^{-}+\mathrm{NH}_{4}^{+}+\mathrm{SO}_{4}^{2-} \\
\mathrm{OH}^{-}+\mathrm{NH}_{4}^{+} \stackrel{k_{2}^{\prime}}{\longrightarrow} \mathrm{NH}_{3}+\mathrm{H}_{2} \mathrm{O} \\
2 \mathrm{C}_{5} \mathrm{H}_{10} \mathrm{~N}^{+}=\mathrm{N}^{-} \rightarrow \mathrm{C}_{5} \mathrm{H}_{10} \mathrm{NN}=\mathrm{NNC}_{5} \mathrm{H}_{10}
\end{gathered}
$$

The resolution of this model shows that the yield of NAPP only depends on two variables. The first one is the $\mathrm{p}$ ratio of the initial molar concentrations $[\mathrm{PP}]_{0} /[\mathrm{HOSA}]_{0}$ and the second one, the ratio of rate constants $k_{2} / k_{1}$.

This reaction model was validated in concentrated medium $(1.2<\mathrm{p}<12 ; 283<\mathrm{T}<373 \mathrm{~K})$. Figure 1 shows a modelled kinetic behaviour of a mixture with industrial concentrations.

The optimal conditions for the synthesis were then determined as follows:

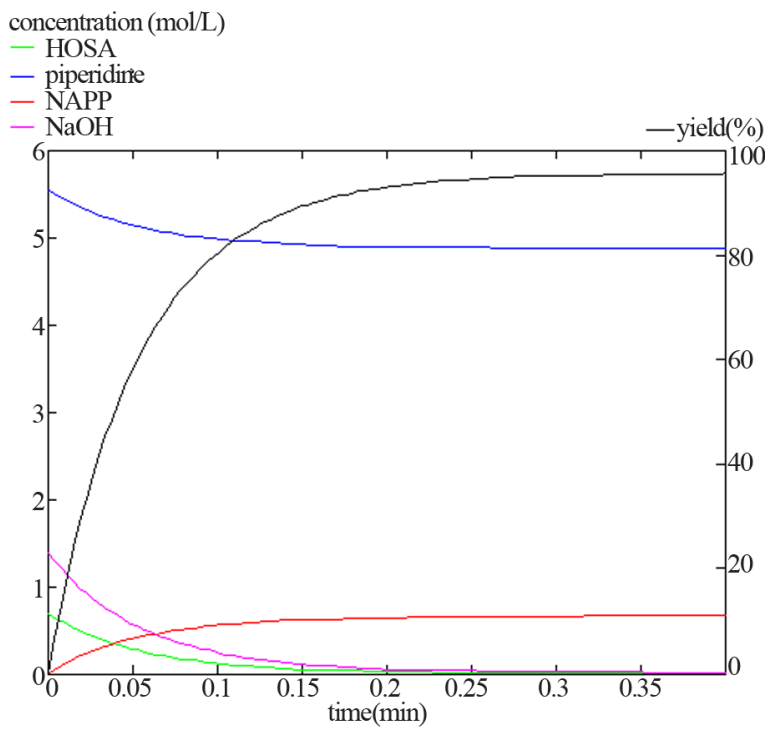

Figure 1. Evolution of the modelled instantaneous concentrations during the synthesis, in basic medium and in industrial conditions $\left([\mathrm{HOSA}]_{0}=0.69 \mathrm{M}\right.$; $[\mathrm{PP}]_{0}=5.55 \mathrm{M}$; $[\mathrm{NaOH}]_{0}=1.39 \mathrm{M} ; \mathrm{T}=293 \mathrm{~K} ; \mathrm{p}=8$ ).
- Aqueous solution of HOSA $32 \mathrm{w} \%$ (0.69 M)

- Aqueous solution of PP $66 \mathrm{w} \%$ (5.55 M)

- Sodium hydroxide (1.39 M)

- Synthesis temperature: $293 \mathrm{~K}$

The reaction is almost ended after 0.35 second and gives NAPP with $96 \%$ yield.

A kinetic study of the formation of NAPP was also realized in buffer medium. The synthesis of NAPP in buffer medium implies the two following parallel reactions:

$$
\begin{gathered}
\mathrm{NH}_{2} \mathrm{OSO}_{3} \mathrm{H}+\mathrm{C}_{5} \mathrm{H}_{10} \mathrm{NH} \stackrel{k_{3}}{\longrightarrow} \mathrm{NH}_{2} \mathrm{OSO}_{3} \mathrm{H}+\mathrm{C}_{5} \mathrm{H}_{10} \mathrm{NH} \\
2 \mathrm{C}_{5} \mathrm{H}_{10} \mathrm{NH}+\mathrm{H}_{2} \mathrm{SO}_{4} \rightarrow\left(\mathrm{C}_{5} \mathrm{H}_{10} \mathrm{NH}_{2}\right)_{2} \mathrm{SO}_{4}
\end{gathered}
$$

Leading to the global reaction:

$$
\begin{aligned}
& \mathrm{NH}_{2} \mathrm{OSO}_{3} \mathrm{H}+3 \mathrm{C}_{5} \mathrm{H}_{10} \mathrm{NH} \rightarrow \\
& \mathrm{C}_{5} \mathrm{H}_{10} \mathrm{NNH}_{2}+\left(\mathrm{C}_{5} \mathrm{H}_{10} \mathrm{NH}_{2}\right)_{2} \mathrm{SO}_{4}
\end{aligned}
$$

The $\mathrm{pH}$ is thus controlled by the buffer mixture piperidine/piperidinium sulphate salt. During the synthesis, 3 moles of PP are consumed to give one mole of NAPP and one mole of piperidinium sulphate salt. It involves the theoretical stoiechiometric relations:

$$
-\frac{\mathrm{d}[\text { HOSA }]}{\mathrm{d} t}=-\frac{1}{3} \frac{\mathrm{d}[\mathrm{PP}]}{\mathrm{d} t}=\frac{\mathrm{d}[\mathrm{NAPP}]}{\mathrm{d} t}
$$

The rate constant $k_{3}$ of formation of NAPP in buffer medium at $293 \mathrm{~K}$ was then determined:

$k_{3}=2.56 \pm 0.08 \mathrm{M}^{-1} \cdot \mathrm{min}^{-1}$ at $293 \mathrm{~K}$.

The formation of a piperidinium salt leads to a slow down in the synthesis reaction of NAPP.

Figure 2 shows the evolution of NAPP yield in basic and buffer media as function of the $\mathrm{p}$ ratio.

This graph shows that, when $\mathrm{p} \geq 8$, the NAPP yields are the same. So, it is also possible to implement this synthesis in buffered medium with the optimal conditions obtained in basic medium.

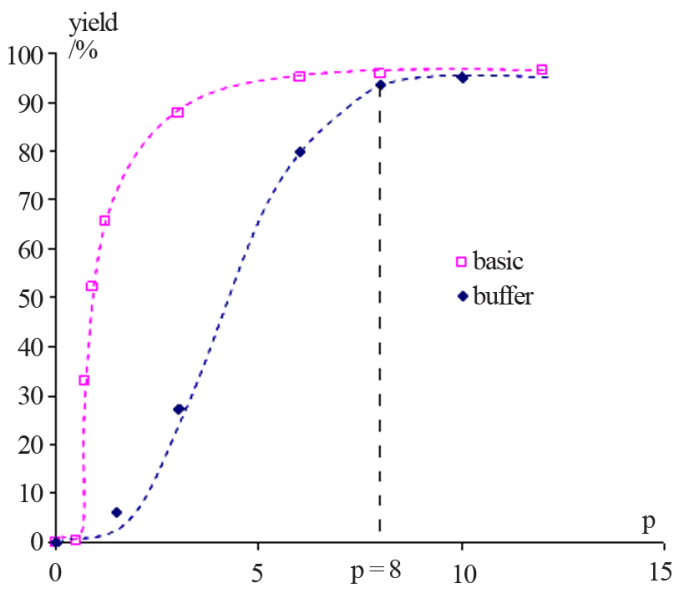

Figure 2. Evolution of the NAPP yield in basic and buffer media as function of the $p$ ratio (with $p=[\mathrm{PP}]_{0} /[\mathrm{HOSA}]_{0}$ ). 
We decided to synthesize NAPP in buffer medium with the following conditions:

- Aqueous solution of HOSA $32 \mathrm{w} \%(0.69 \mathrm{M})$

- Aqueous solution of PP $66 \mathrm{w} \%(5.55 \mathrm{M})$

- Synthesis temperature: $293 \mathrm{~K}$

At the end of the synthesis, the crude solutions are complex and diluted. The extraction process was optimized thanks to the study of the phase diagrams involved. The first step of the extraction consists of a demixing generated in-situ by the sodium sulphate released after neutralization of the piperidinium salt by sodium hydroxyde. Four isothermal sections [16] of the solid-liquidliquid $\mathrm{H}_{2} \mathrm{O}-\mathrm{Na}_{2} \mathrm{SO}_{4}-\mathrm{C}_{5} \mathrm{H}_{10} \mathrm{NH}$ ternary diagram were established at 293, 298, 313 and $323 \mathrm{~K}$ under atmospheric pressure by Isoplethic Thermal Analysis (ITA) [17]. A polythermic diagram was then designed between 293 and $323 \mathrm{~K}$ [18]. Figures 3(a) and 3(b) show respectively the isotherm 293 and $313 \mathrm{~K}$ expressed in mass fractions, under atmospheric pressure.

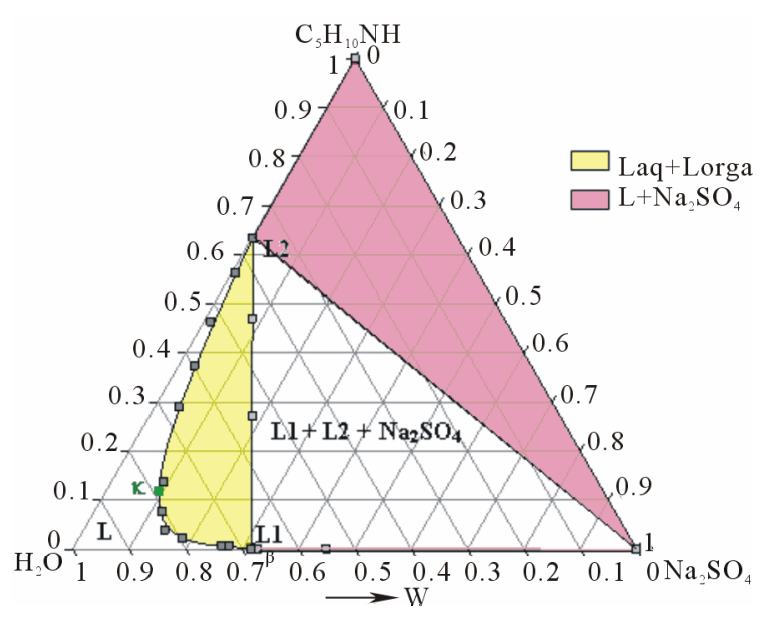

(a)

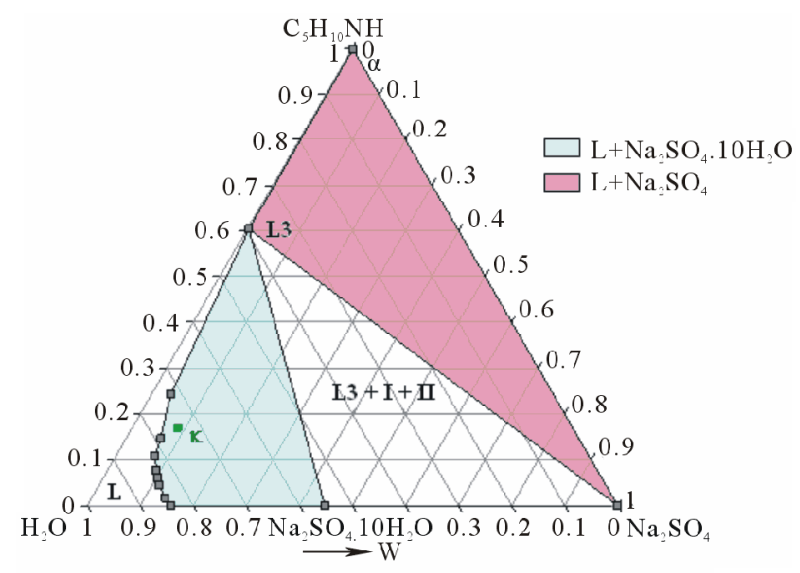

(b)

Figure 3. (a) Ternary system $\mathrm{H}_{2} \mathrm{O}-\mathrm{Na}_{2} \mathrm{SO}_{4}-\mathrm{C}_{5} \mathrm{H}_{10} \mathrm{NH}$ : isotherm $293 \mathrm{~K}$ (mass fractions), $\mathrm{P}=1$ bar. $\mathrm{I}: \mathrm{Na}_{2} \mathrm{SO}_{4} \cdot 10 \mathrm{H}_{2} \mathrm{O}$; II: $\mathrm{Na}_{2} \mathrm{SO}_{4}$. (b) Ternary system $\mathrm{H}_{2} \mathrm{O}-\mathrm{Na}_{2} \mathrm{SO}_{4}-\mathrm{C}_{5} \mathrm{H}_{10} \mathrm{NH}$ : isotherm $313 \mathrm{~K}$ (mass fractions), $P=1$ bar.
The second step is a demixing induced by addition of sodium hydroxide. This one allows concentrating the organic compounds in order to optimize the next distillation operations. This step required thus the study of the solid-liquid-liquid $\mathrm{H}_{2} \mathrm{O}-\mathrm{NaOH}-\mathrm{C}_{5} \mathrm{H}_{10} \mathrm{NH}$ ternary diagram. Three isothermal sections were established at 293, 313 and $323 \mathrm{~K}$ by ITA [19]. Figures 4(a) and 4(b) show respectively the isotherm 293 and $323 \mathrm{~K}$ expressed in mass fractions, under atmospheric pressure.

The final step of the extraction process consists of a distillation of the recovered organic phase mixture composed of water, PP and NAPP ( $46.5 \mathrm{w} \%$ water; $45.6 \mathrm{w} \%$ PP; 7.9 w\% NAPP). In order to optimize this step, we studied the liquid-vapour $\mathrm{H}_{2} \mathrm{O}-\mathrm{C}_{5} \mathrm{H}_{10} \mathrm{NH}-\mathrm{C}_{5} \mathrm{H}_{10} \mathrm{NNH}_{2}$ ternary diagram. The three limit binary systems, $\mathrm{H}_{2} \mathrm{O}$ $\mathrm{C}_{5} \mathrm{H}_{10} \mathrm{NH}, \mathrm{H}_{2} \mathrm{O}-\mathrm{C}_{5} \mathrm{H}_{10} \mathrm{NNH}_{2}$ and $\mathrm{C}_{5} \mathrm{H}_{10} \mathrm{NH}-\mathrm{C}_{5} \mathrm{H}_{10} \mathrm{NNH}_{2}$, were established by ebulliometry under atmospheric pre-

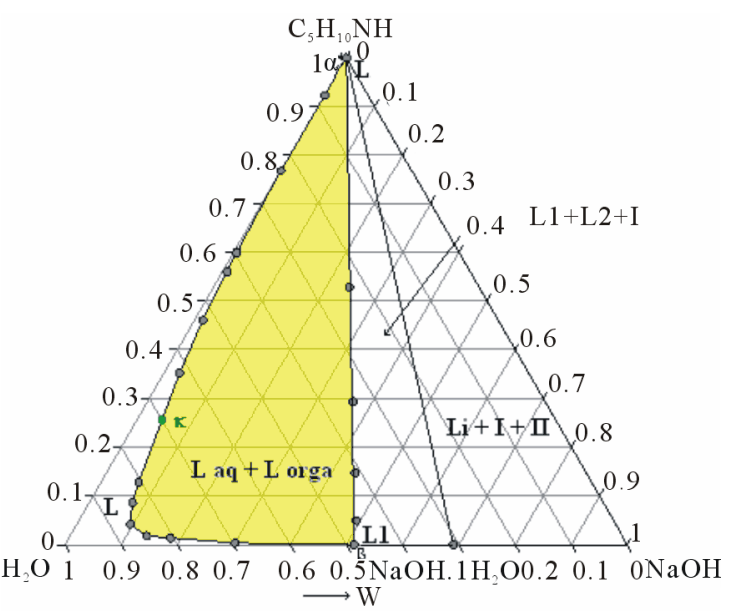

(a)

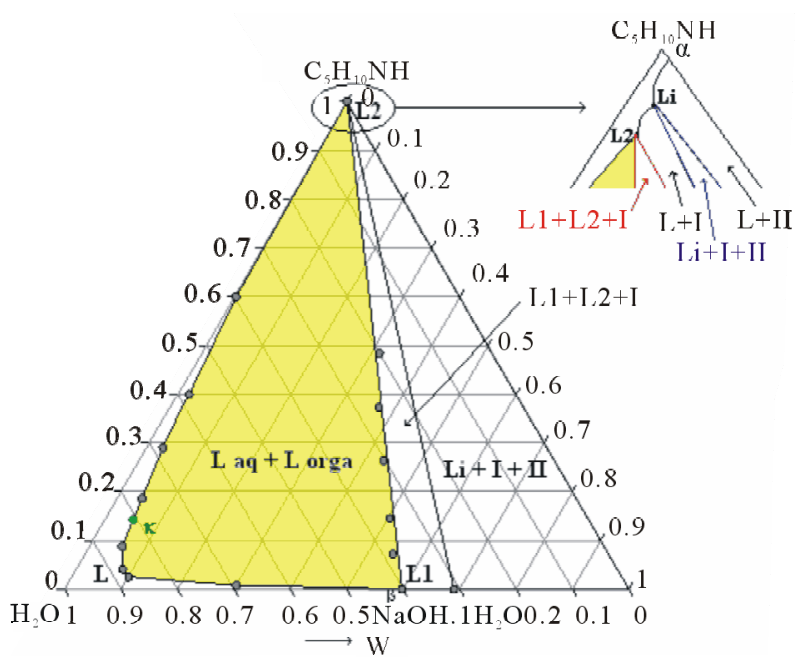

(b)

Figure 4. (a) Ternary system $\mathrm{H}_{2} \mathrm{O}-\mathrm{NaOH}-\mathrm{C}_{5} \mathrm{H}_{10} \mathrm{NH}$ : isotherm $293 \mathrm{~K}$ (mass fractions), $\mathrm{P}=1 \mathrm{bar}, \mathrm{I}: \mathrm{NaOH} \cdot \mathrm{H}_{2} \mathrm{O}$, II: $\mathrm{NaOH}$. (b) Ternary system $\mathrm{H}_{2} \mathrm{O}-\mathrm{NaOH}-\mathrm{C}_{5} \mathrm{H}_{10} \mathrm{NH}$ : isotherm $293 \mathrm{~K}$ (mass fractions), $\mathrm{P}=1 \mathrm{bar}, \mathrm{I}: \mathrm{NaOH} \cdot \mathrm{H}_{2} \mathrm{O}$, II: $\mathrm{NaOH}$. 
ssure. The liquid-vapour $\mathrm{H}_{2} \mathrm{O}-\mathrm{C}_{5} \mathrm{H}_{10} \mathrm{NH}-\mathrm{C}_{5} \mathrm{H}_{10} \mathrm{NNH}_{2}$ ternary diagram is characterized by two distillation domains, linked to the existence of a positive azeotropic mixture in the $\mathrm{H}_{2} \mathrm{O}-\mathrm{C}_{5} \mathrm{H}_{10} \mathrm{NH}$ binary system. Figure 5 shows the $\mathrm{H}_{2} \mathrm{O}-\mathrm{C}_{5} \mathrm{H}_{10} \mathrm{NH}-\mathrm{C}_{5} \mathrm{H}_{10} \mathrm{NNH}_{2}$ polythermal ternary system under atmospheric pressure.

The experimental coordinates of the $\mathrm{H}_{2} \mathrm{O}-\mathrm{PP}$ azeotropic mixture are:

$$
\begin{aligned}
& \mathrm{x}\left(\mathrm{C}_{5} \mathrm{H}_{10} \mathrm{NH}\right)=0.661 \\
& \mathrm{~T}_{\text {vap }}=364.95 \mathrm{~K}
\end{aligned}
$$

To secure the process, two measurement sets of mixing enthalpies were realized at $298 \mathrm{~K}$, by mixing calorimetry. The first series concerns the solvation enthalpies of HOSA-water and PP-water binary mixtures. The second one, focused on the measurement of the reaction enthalpy of NAPP according to the dilution of the reagent involved, allowed us to determine the hypothetical reaction enthalpy in anhydrous medium. The infinite dilution enthalpy is equal to $-140 \mathrm{~kJ} / \mathrm{mol}$ and the enthalpy in anhydrous medium is estimated at $-340 \mathrm{~kJ} / \mathrm{mol}$. The exothermicity of the reaction requires thus the necessity of an impressive cooling of the synthesis reactor in order to manage the temperature of the medium.

\section{Process Design}

We can propose two different processes depending on whether PP is injected anhydrous or as an azeotropic mixture of PP in water ( $66 \mathrm{w} \% \mathrm{PP})$.

In both cases, the first step consists in carrying out the synthesis reaction at $293 \mathrm{~K}$, in a buffer medium and with

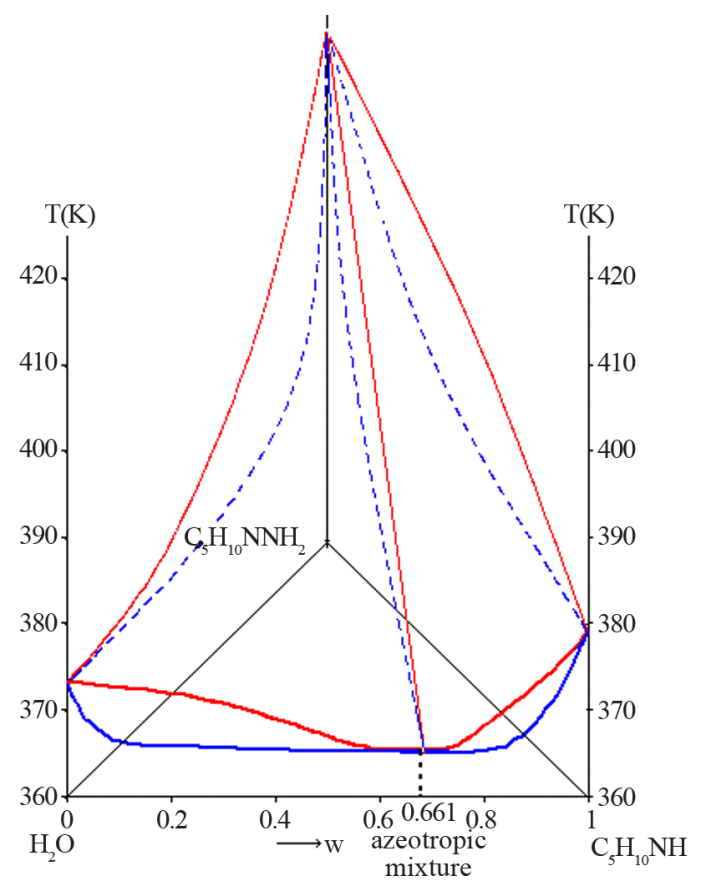

Figure 5. Liquid-vapour $\mathrm{H}_{2} \mathrm{O}-\mathrm{C}_{5} \mathrm{H}_{10} \mathrm{NH}-\mathrm{C}_{5} \mathrm{H}_{10} \mathrm{NNH}_{2}$ ternary system, $\mathbf{P}=1$ bar (mass fractions). a molar ratio of initial concentrations

$\left[\mathrm{C}_{5} \mathrm{H}_{10} \mathrm{NH}\right]_{0} /\left[\mathrm{NH}_{2} \mathrm{OSO}_{3} \mathrm{H}\right]_{0}$ equals to 8 . The NAPP yield reaches then $93 \%$.

After the synthesis, the crude mixture is mainly composed of NAPP, piperidinium sulphate salt, PP in excess, water and some by-products (tetrazene and triazanium salt derivatives). In a second operation, we add a $32 \mathrm{w} \%$ aqueous solution of sodium hydroxide which generates sodium sulphate by neutralization of the piperidinium salt and induced the salting-out.

$\mathrm{G}_{\mathrm{anh}}$ is the mass composition of the crude mixture obtained after the NAPP synthesis by injection of anhydrous PP and neutralization of the salt. $\mathrm{G}_{\mathrm{az}}$ is the mass composition of the crude mixture after addition of an azeotropic mixture of PP and water and neutralization of the salt at the end of the NAPP synthesis. These two compositions are the following:

$$
\mathrm{G}_{\text {anh }}=44.7 \mathrm{w} \% \text { PP; } 12.5 \mathrm{w} \% \mathrm{Na}_{2} \mathrm{SO}_{4} ; 42.8 \mathrm{w} \% \mathrm{H}_{2} \mathrm{O} \text {. }
$$

$\mathrm{G}_{\mathrm{az}}=33.1 \mathrm{w} \%$ PP; $9.9 \mathrm{w} \% \mathrm{Na}_{2} \mathrm{SO}_{4} ; 57 \mathrm{w} \% \mathrm{H}_{2} \mathrm{O}$.

As shows the isotherm $293 \mathrm{~K}$ of the solid-liquid $\mathrm{H}_{2} \mathrm{O}$ $\mathrm{Na}_{2} \mathrm{SO}_{4}-\mathrm{C}_{5} \mathrm{H}_{10} \mathrm{NH}$ ternary diagram (Figure 6), the $\mathrm{G}_{\mathrm{az}}$ and $\mathrm{G}_{\text {anh }}$ points are located respectively in the $\mathrm{L}+$ $\mathrm{Na}_{2} \mathrm{SO}_{4} \cdot 10 \mathrm{H}_{2} \mathrm{O}$ and the $\mathrm{L} 3+\mathrm{Na}_{2} \mathrm{SO}_{4} \cdot 10 \mathrm{H}_{2} \mathrm{O}+\mathrm{Na}_{2} \mathrm{SO}_{4}$ domains.

At this temperature, any demixing zone appears.

But at $313 \mathrm{~K}$ (Figure 7), $\mathrm{G}_{\mathrm{az}}$ and $\mathrm{G}_{\mathrm{anh}}$ are respectively located in the demixing zone and in the $\mathrm{L} 1+\mathrm{L} 2+$ $\mathrm{Na}_{2} \mathrm{SO}_{4}$ triphasic domains.

It is thus preferable to synthesize NAPP starting from an azeotropic mixture of PP and water and implement the neutralization of the piperidinium salt at $313 \mathrm{~K}$. In these conditions there is no precipitation of anhydrous sodium sulphate. After the neutralization step, the recovered organic liquid $\mathrm{M}$ is mainly composed of water $(46.5 \mathrm{w} \%)$, PP (45.6 w\%) and NAPP (7.9 w\%).

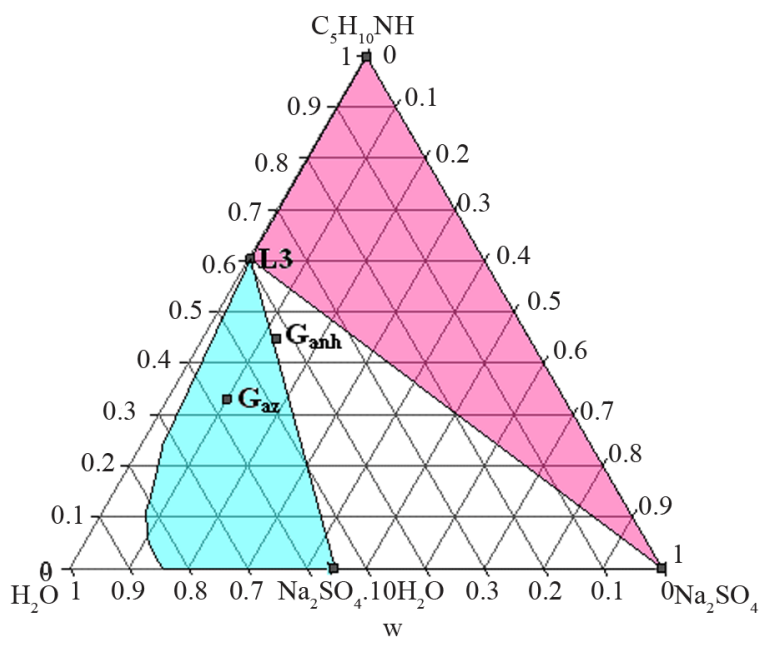

Figure 6. Isotherm $293 \mathrm{~K}$ of the solid-liquid $\mathrm{H}_{2} \mathrm{O}-\mathrm{Na}_{2} \mathrm{SO}_{4}$ $\mathrm{C}_{5} \mathrm{H}_{10} \mathrm{NH}$ ternary diagram, $P=1$ bar. Location of the $G_{a n h}$ and $G_{a z}$ crude mixtures. 
Looking at the liquid-vapour ternary system, the mixture $\mathrm{M}$ is in fact located in the water/azeotrope/NAPP distillation field (Figure 8).

In this configuration, two successive distillation operations are required to get rid of the azeotropic mixture and the water in excess and finally a third distillation, under reduced pressure, permits to obtain the product in conformity with the pharmaceutical applications (purity up to $99 \mathrm{w} \%$ ).

In order to simplify the distillation process, we preferred to dehydrate partially the organic liquid $M$ thanks to a demixing observed in the solid-liquid-liquid $\mathrm{H}_{2} \mathrm{O}$ $\mathrm{NaOH}-\mathrm{C}_{5} \mathrm{H}_{10} \mathrm{NH}$ ternary system.

The aim of this step is to generate a new demixing by addition of an aqueous solution of sodium hydroxide (50 $\% \mathrm{w})$. The added quantity of soda was optimized in order to obtain an organic phase with a mass composition very close to those of the azeotrope. This organic liquid M' is then composed of water (31.8 w\%), PP (59.2 w\%) and NAPP (9 w\%).
This mixture $M^{\prime}$ is very near the monoazeotropic distillation curve (Figure 9).

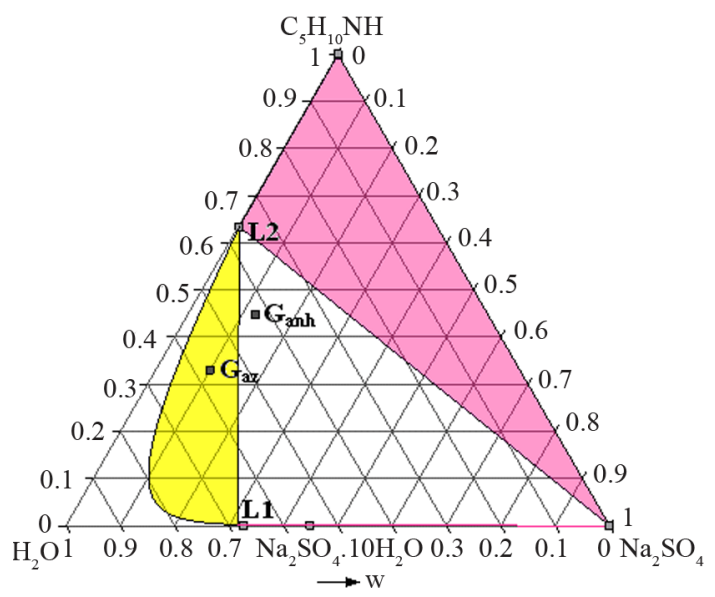

Figure 7. Isotherm $313 \mathrm{~K}$ of the solid-liquid $\mathrm{H}_{2} \mathrm{O}-\mathrm{Na}_{2} \mathrm{SO}_{4}$ $\mathrm{C}_{5} \mathrm{H}_{10} \mathrm{NH}$ ternary system, $P=1$ bar. Location of the $G_{a n h}$ and $G_{a z}$ crude mixtures.

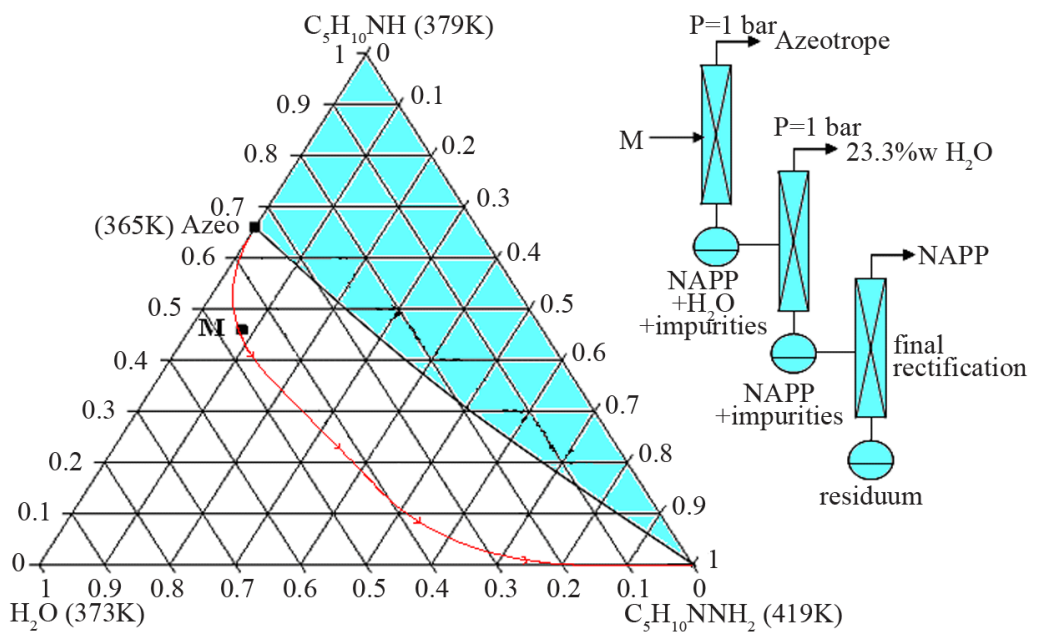

Figure 8. Distillation trajectory of the organic liquid M (water 46.5 w\%, PP 45.6 w\%, NAPP 7.9 w\%).

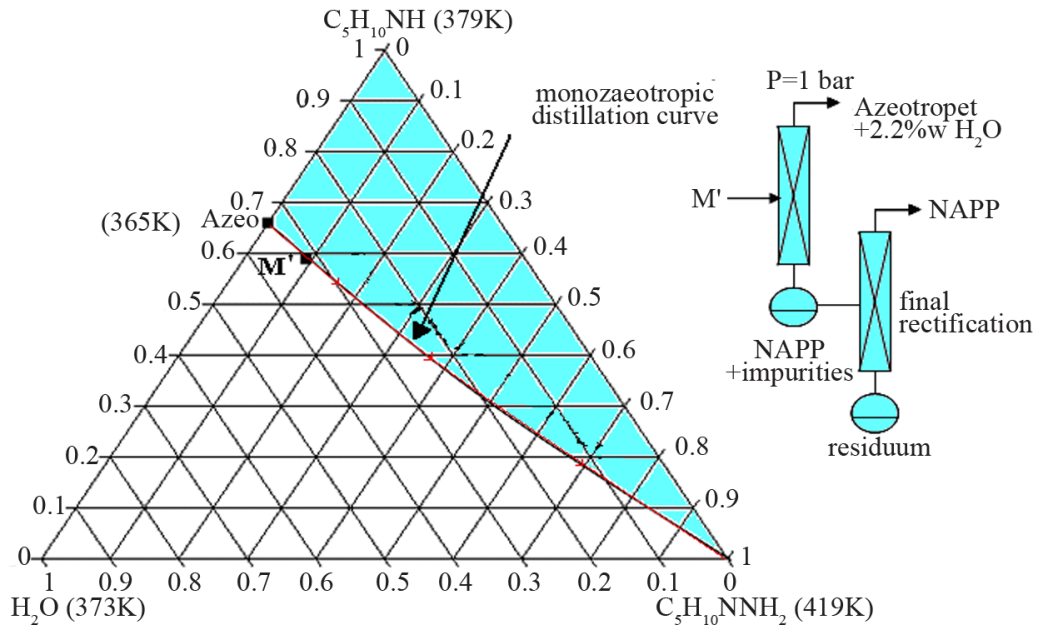

Figure 9. Distillation trajectory of the organic liquid M' (water 31.8 w\%, PP 59.2 w\%, NAPP 9 w\%). 
In these optimized conditions, two successive distillations are thus necessary to obtain anhydrous NAPP. The small excess of water has no impact on the final yield of NAPP. The azeotropic mixture with $2.2 \mathrm{w} \%$ of water can be directly injected upstream from the synthesis (Figure 10).
For the anhydrous version process (Figure 11), we can totally dehydrate the organic liquid $\mathrm{M}$ thanks to a demixing observed in the solid-liquid-liquid $\mathrm{H}_{2} \mathrm{O}-\mathrm{NaOH}-$ $\mathrm{C}_{5} \mathrm{H}_{10} \mathrm{NH}$ ternary system. Experimentally, this step is fastidious and requires several runs of soda additions and filtrations. At the end of this step, we obtain then an or-

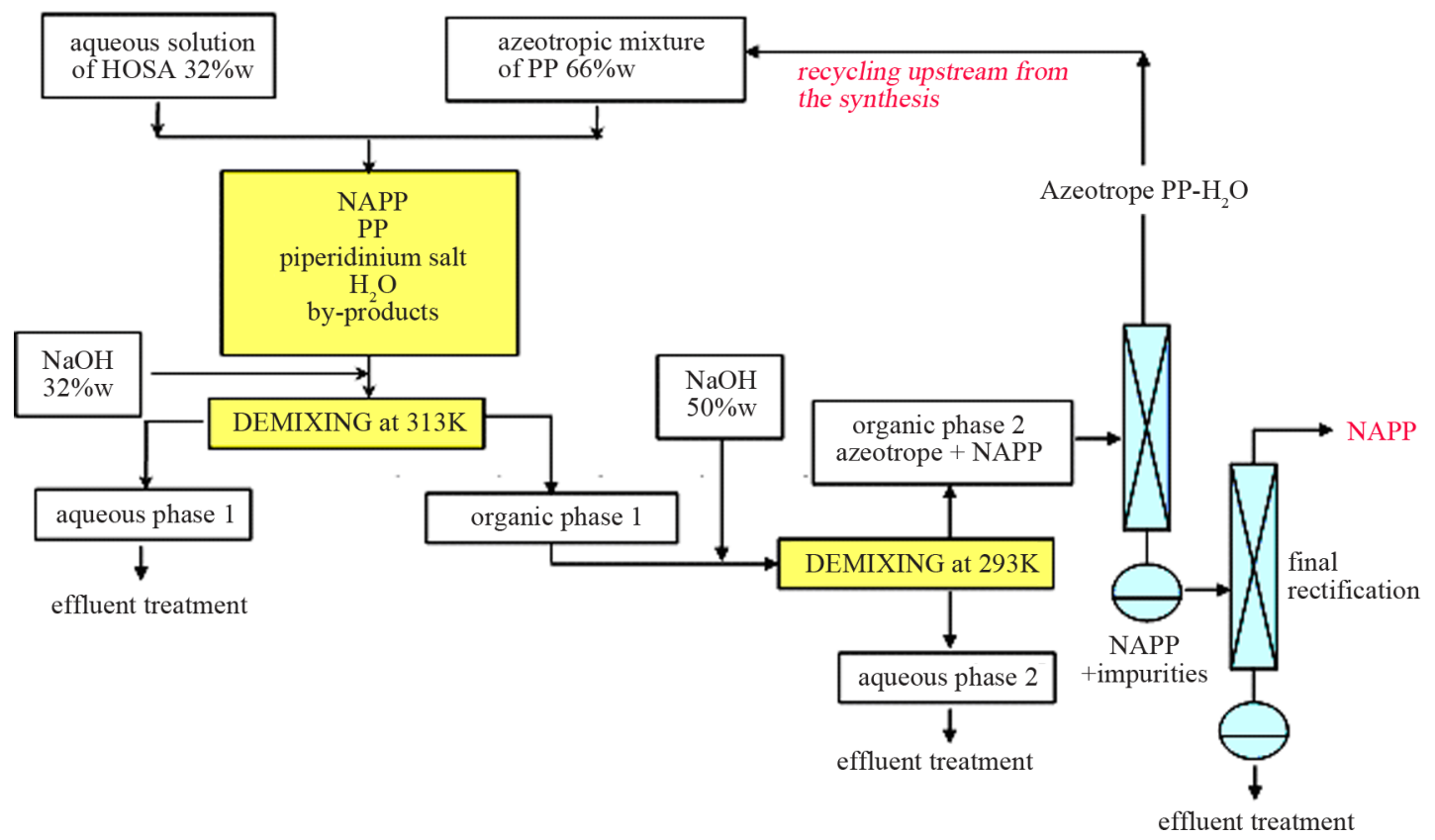

Figure 10. Process with PP-water azeotropic mixture.

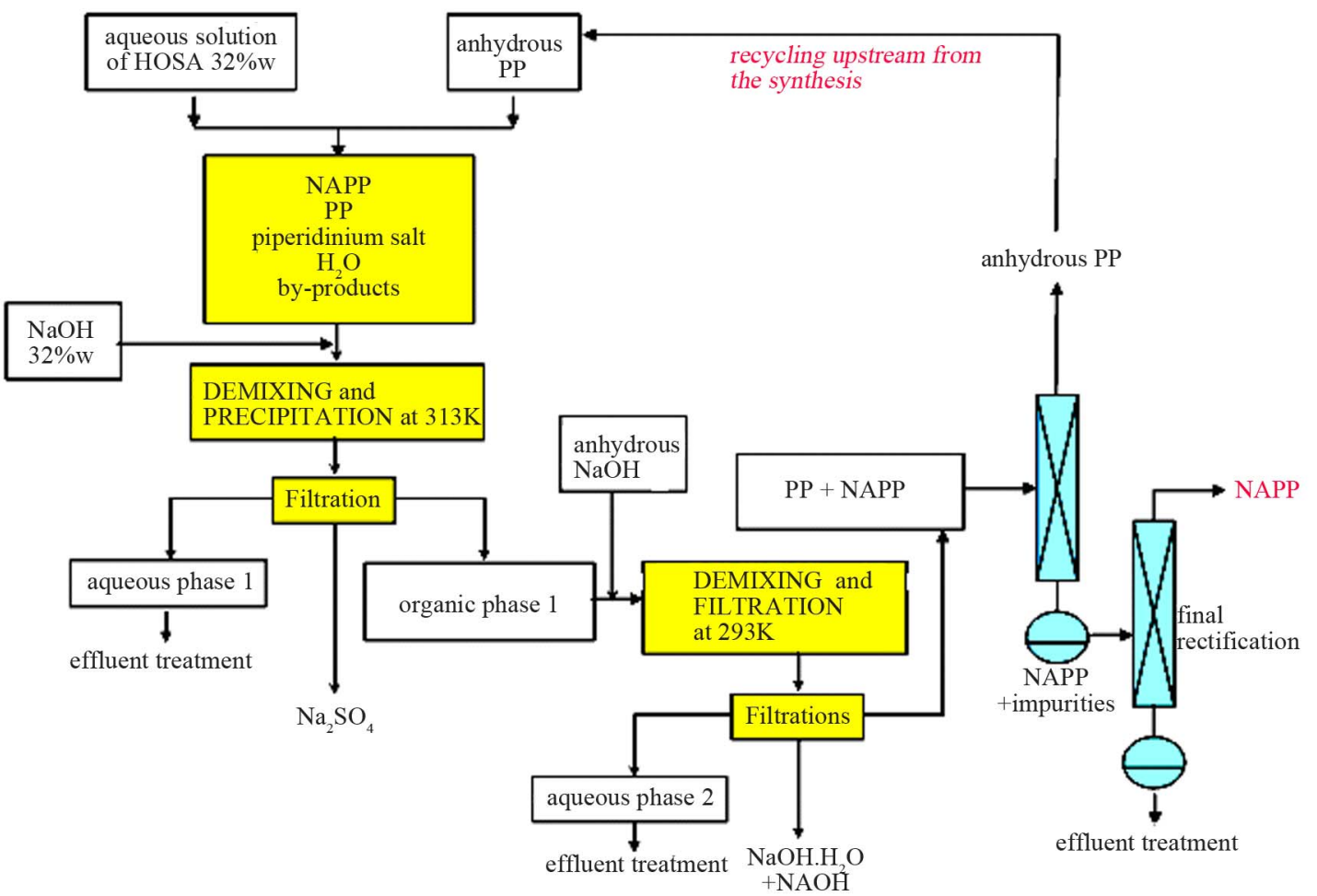

Figure 11. Process with anhydrous PP. 
ganic phase mainly composed of PP and NAPP and it becomes easy to separate the two compounds by distillation. However, the organic phase is not anhydrous and contains a small amount of water. So, during the distillation, we recover a small fraction of the $\mathrm{H}_{2} \mathrm{O}-\mathrm{PP}$ azeotropic mixture, which is economically necessary to retreat.

The synthesis using azeotropic mixture of water and PP is more adapted, for a batch or a continuous process, with a minimum of extraction operations and all steps are carried out in fluid phase.

\section{Conclusions}

The synthesis of NAPP was optimized thanks to kinetic studies. In order to obtain a $96 \%$ yield of NAPP, the synthesis is realized at $293 \mathrm{~K}$ with an excess of PP ( $\mathrm{p}=$ 8 ), in buffer medium.

The extraction parameters were defined thanks to a relevant exploitation of the phase diagrams involved. It consists of two successive demixings and two distillations. The final product is anhydrous and contains any by-product.

Two global processes of synthesis and extraction of NAPP were developed, one using anhydrous PP and the other, the $\mathrm{PP}-\mathrm{H}_{2} \mathrm{O}$ azeotropic mixture. The process with the azeotropic mixture seems to be the most relevant and flexible.

\section{Acknowledgements}

Thanks to the Région Rhone-Alpes FRANCE: Study funded by EMERGENCE Project 2005-2008.

\section{REFERENCES}

[1] F. Barth and P. Casellas, "Substituted N-Piperidino 3Pyrazolecarboxamide," European Patent 0656354, 1995.

[2] C. G. Kruse, J. H. M. Lange, A. H. J. Herremans and H. H. Van Stuivenberg, "H-Imidazole Derivatives Having $\mathrm{CB}_{1}$ Agonistic, $\mathrm{CB}_{1}$ Partial Agonistic or $\mathrm{CB}_{1}$-Antagonistic Activity," International Patent WO03027076, 2003.

[3] C. G. Kruse, J. H. M. Lange, T. Jacobus, A. H. J. Herremans and H. H. Van Stuivenberg, "Novel 4,5-Dihydro1H-pyrazole Derivatives Having $\mathrm{CB}_{1}$-Antagonistic Activity," International Patent WO03026647, 2003.

[4] A. R. Stoit, J. H. M. Lange, A. P. Den Hartog, E. Ronken, K. Tipker, H. H. Van Stuivenberg, J. A. R. Dijksman, H. C. Wals and C. G. Kruse, "Design, Synthesis and Biological Activity of Rigid Cannabinoid $\mathrm{CB}_{1}$ Receptor Antagonists," Chemical and Pharmaceutical Bulletin, Vol. 50, No. 8, 2002, pp. 1109-1113. doi:10.1248/cpb.50.1109

[5] P. E. Finke, S. G. Mills, C. W. Plummer, S. K. Shah and Q. T. Truong, "Substituted Imidazoles as Cannabinoid Receptor Modulators," International Patent WO03007887, 2003.

[6] W. K. Hagmann, H. Qi and S. K. Shah, "Substituted Imi- dazoles as Cannabinoid Receptor Modulators," International Patent WO03063781, 2003.

[7] R. A. Smith, S. J. O'Connor, S. N. Wirtz, C. Wong Wai, S. Choi, H. C. Kluender, N. Su, G. Wang, F. Achebe and S. Ying, "Imidazole-4-carboxamide Derivatives, Preparation and Use Thereof for Treatment of Obesity," International Patent WO03040107, 2003.

[8] R. A. Smith, H. C. Kluender, N. Su, R. C. Lavoie and J. Fan, "Preparation and Use of Pyrrole Derivatives for Treating Obesity," International Patent WO03027069, 2003.

[9] A. L. Hildebrandt, D. M. Kelly-Sullivan and S. C. Black, "Antiobesity Effects of Chronic Cannabinoid $\mathrm{CB}_{1}$ Receptor Antagonist Treatment in Diet-Induced Obese Mice," European Journal of Pharmacology, Vol. 462, No. 1-3, 2003, pp. 125-132. doi:10.1016/S0014-2999(03)01343-8

[10] J. M. Wilsterman and A. I. K. Berggren, "Pyrazine Compounds and Pharmaceutical Compositions Containing them," International Patent WO03051850, 2003.

[11] A. I. K. Berggren, S. J. Bostrom, S. T. Elebring, P. Greasley, E. Terricabra and J. M. Wilstermann, "5,6-Diaryl-pyrazine-2-amide Derivatives as $\mathrm{CB}_{1}$ Antagonists," International Patent WO03051851, 2003.

[12] S. Liu, "N-Substituted 3-Hydroxy-4-pyridinones and Pharmaceuticals Containing Thereof," International Patent WO03065991, 2003.

[13] B. S. Muehl, “3-Benzyl-benzothiophenes," US Patent 6417199, 2002.

[14] J. Dumas, W. Lee, Y. Chen, L. Adnane, W. Scott, S. Verna, J. Chen, Z. Chen and L. Yi, "Substituted Pyridine Derivatives Useful in the Treatment of Cancer and Other Disorders," European Patent 1603879, 2005.

[15] E. Labarthe, A. J. Bougrine, V. Pasquet and H. Delalu, "Kinetic Modelling of Synthesis of N-Aminopiperidine from Hydroxylamine-O-sulfonic Acid and Piperidine," Kinetics and Catalysis, Vol. 53, No. 1, 2012, pp. 25-35. doi:10.1134/S0023158412010041

[16] E. Labarthe, A. J. Bougrine, H. Delalu, J. Berthet and J. J. Counioux, "Equilibrium Study between Condensed Phases by Isoplethic Thermal Analysis When a Miscibility Gap Is Observed," Journal of Thermal Analysis and Calorimetry, Vol. 95, No. 1, 2009, pp. 135-139. doi:10.1007/s10973-008-9000-8

[17] J. Berthet and J. J. Counioux, "Procédé et Dispositif de Mesure de la Solubilité d'au Moins un Soluté Solide, Liquide ou Gazeux dans un Solvant, Par Analyse Thermique Isopléthique," French Patent 9313402, 1993.

[18] E. Labarthe, A. J. Bougrine, J. Berthet and H. Delalu, "Study of the Polythermal Diagram Water-Sodium Sulphate-Piperidine," Journal of Themal Analysis and Calorimetry, Vol. 100, No. 3, 2010, pp. 1099-1105. doi:10.1007/s10973-009-0567-5

[19] E. Labarthe, A. J. Bougrine and H. Delalu, "Extraction Optimization of Organic Compounds by Demixing Observed in the $\mathrm{H}_{2} \mathrm{O}-\mathrm{NaOH}$-Piperidine Ternary Diagram," Journal of Themal Analysis and Calorimetry, Vol. 102, No. 3, 2010, pp. 1119-1122. doi:10.1007/s10973-010-0744-6 